\title{
Economic evaluation of hazard control technology in a wet process cement plant
}

\author{
Olasunkanmi Oriola Akinyemi ${ }^{1}$, Hezekiah Oluwole Adeyemi ${ }^{1}$, Adeshinaayomi Lawal Akintan' \\ Musediq Adedoyin Sulaiman¹, Ademola Oluwafemi Sadiq1, Olaolu Folorunsho² \\ ${ }^{1}$ Olabisi Onabanjo University, Department of Mechanical Engineering, Ago-Iwoye, Nigeria. \\ ${ }^{2}$ Olabisi Onabanjo University, Department of Computer Engineering, Ago-Iwoye, Nigeria.
}

How to cite: Akinyemi, O.O., Adeyemi, H.O., Akintan, A.L. et al. (2021), “Economic evaluation of hazard control technology in a wet process cement plant", Brazilian Journal of Operations \& Production Management, Vol. 18, No. 1, e2021961. https://doi.org/10.14488/BJOPM.2021.005

\begin{abstract}
Goal: Retrofit technology has been suggested for the reduction of $\mathrm{CO}_{2}$ emission in cement manufacturing but the economic justification of this retrofit technology is rarely or not available. This research study aimed to evaluate the beneficial value of retrofit technology aimed at reducing $\mathrm{CO}_{2}$ emission in a wet process cement plant.
\end{abstract}

Design / Methodology / Approach: Engineering Economic and cost estimation techniques were used to evaluate the overall annual cost of combination of retrofit technology. The overall annual cost of retrofit technology was determined in terms of capital cost, operation and maintenance cost and energy cost savings of retrofit.

Results: The best strategy to reduce $\mathrm{CO}_{2}$ emission is the combination of adjustable speed drive for kiln; kiln drive efficiency improvement for kiln and process control and management system for kiln at $6 \%$ reduction target, giving a cost savings of $\$ 520,836$ on retrofit for 10 years and $1.41 \%$ reduction in total cost.

Limitations of the investigation: Getting adequate plant data in Nigeria was a constraint during the research.

Practical implications: The results presented if implemented by Cement plant operators will ensure reduction in the $\mathrm{CO}_{2}$ emission and government can enforce Cement plant operators to adhere to strict environmental and safety regulations while litigations and sanctions can be employed to implements this policy.

Originality / Value: The study established economic justification of retrofit technology for $\mathrm{CO}_{2}$ emission reduction before eventual implementation.

Keywords: Cost Saving; Emission; Hazards; Kiln; Retrofitting; Wet Process.

\section{INTRODUCTION}

Cement no doubt, is a much desired commodity and our development as a country isn't an extended way-fetched from our infrastructural power in terms of homes and awesome bodily infrastructure (Global Cement (2011). Cement consequently performs an important role in this regard. There are two techniques used for the manufacture of cement namely wet process and dry Process (Sidhi et. al., 2016). The decision among wet and dry techniques relies upon on positive factors specifically the physical condition of the raw substances; the cost of the fuel and the local climatic condition of the manufacturing unit. The particular feature of the wet system is that the raw materials are mixed in water while inside the dry technique the

Financial support: None.

Conflict of interest: The authors have no conflict of interest to declare.

Corresponding author: ooakinyemi@oouagoiwoye.edu.ng

Received: 2 May 2020

Approved: 28 August 2020.

Editor: Julio Vieira Neto and Osvaldo L. G. Quelhas. 
materials are ground and blended dry (International Energy Agency, 2010). Cement is among the most important commodities, as it serves as an excellent constituent inside the making of human refuge. Its manufacturing and availability can't be toyed with but unfortunately, an accompanying pollution is inevitable.

Nigeria is the most populated country in Africa with a population of 200 million individuals. Similarly, the nation has the quickest developing populace on the Africa's landmass with $2.6 \%$ yearly development rate in year 2016. The nation is positioned 44th producer of cement in the rundown of more than 200 World's nations. Be that as it may, with the pace at which the nation's populace is developing, the worry for increment in $\mathrm{CO}_{2}$ emanations, which go with it, similarly develops. In that capacity, all things considered, the nations per capital emission will keep on ascending because of the quick populace development. This will expectedly expand the aggregate $\mathrm{CO}_{2}$ discharges essentially. Along these lines, Nigeria is relied upon to devise maintainable methods for tending to $\mathrm{CO}_{2}$ emanations (Sulaiman and Abdul-Rahim, 2018).

The cement industry has been lively in pursuing techniques to decreased $\mathrm{CO}_{2}$ emanations long earlier than global warming have become a concern. Since 1999, with the launch of the Cement Sustainability Initiative (CSI) at the World Business Council for Sustainable Development (WBCSD), the industry has systematically amassed evidence and stepped forward its techniques. In 2009, the International Energy Agency/World Business Council for Sustainable Development (IEA/WBCSD) Roadmap presented several $\mathrm{CO}_{2}$ emanations and mitigation strategies (IEA, 2018). The IEA study observed that the target $50 \%$ global emissions reduction purpose to preserve global warming at less than $2^{\circ} \mathrm{C}$ of pre-industrial stages might require an average reduction of $18 \%$ within the $\mathrm{CO}_{2}$ emanations of the cement industry by 2050 (Farfan et al., 2019).

Nigeria $\mathrm{CO}_{2}$ emanations data as reported in the World Bank study by Cervigni et al. (2013) indicated that agriculture and land use, oil and gas, power and transport sectors accounted for the majority of the $\mathrm{CO}_{2}$ emanations to the environment. Surprisingly, manufacturing sector and cement industry in particular (with a percentage contribution of $8.14 \%$ to GDP of Nigeria economy in Q3 of 2013) was not included in the study. The Federal Government of Nigeria (FGN) has shown some commitments in combating $\mathrm{CO}_{2}$ emanations. At the 2015 UN Climate Change Conference held in Paris, France; Nigeria presented a document which stated unconditional commitment to reduce $\mathrm{CO}_{2}$ emanations by $20 \%$ in year 2030 and possibility of achieving 45\% reduction outside aid is obtained (Ezema et al., 2016).

Summerbell et al. (2016) and Maddalena et al. (2018) stated that reducing $\mathrm{CO}_{2}$ emanations from cement manufacturing depend largely on raw material mix and fuel type. Summerbell et al. (2016) further stated that the type of manufacturing technology used for cement production also contribute to $\mathrm{CO}_{2}$ emanations. In order to achieve the target of less than $2^{\circ} \mathrm{C}$ global average temperature and environmental gains, it is necessary to implement mitigation strategies for the reduction of $\mathrm{CO}_{2}$ emanation. Also Naqi and Jang (2019) investigated the use of different alternative fuels and binders in cement production to mitigate carbon dioxide emissions. Farfan et al. (2019) and Jessica (2018) proposed carbon capture and utilization (CCU) techniques as a means of reducing $\mathrm{CO}_{2}$ emanations and the possible use of the captured $\mathrm{CO}_{2}$ for the production of synthetic hydrocarbon. Adebiyi et al. (2015) identified four technological approaches (namely adjustable speed drive for kiln, kiln drive efficiency improvement for kiln, process control and management system for kiln and reciprocating grate coolers for kiln) and eighteen combinations (for two production line of kilns) of these technological approaches to reduce $\mathrm{CO}_{2}$ emanations. Gardarsdottir et al., (2019) also identified four $\mathrm{CO}_{2}$ capture technologies namely (chilled ammonia process (CAP), membraneassisted $\mathrm{CO}_{2}$ liquefaction, oxyfuel technology and two different configurations of calcium looping technology (tail-end and integrated)). Other mitigating strategies for $\mathrm{CO}_{2}$ reduction in cement manufacturing have been compiled by Leeson et al. (2017).

However, while an $18 \%$ reduction target of $\mathrm{CO}_{2}$ emission was achieved in the work done by Adebiyi et al. (2015); the economic implications of the retrofit technologies have not been 
proven. So, it is the main objective of this research work to evaluate the economic viability of combination of retrofit technology in a wet process cement plant.

\section{METHODOLOGY}

In order to evaluate the economic viability of retrofit technology for mitigating $\mathrm{CO}_{2}$ emanations in a wet process cement plant; the following methodologies were used:

1. Cost estimation; and

2. Engineering Economic techniques.

The cost estimation approach was used to estimate the capital cost, operations and maintenance cost and energy savings of retrofit technology in year 2008 while the engineering economic techniques was used to evaluate all cost parameters from the estimated cost in 2008 to year 2019 i.e. discounting the value estimated in year 2008 to year 2019 value and subsequently annualized over a 10-year period.

\section{Cost Estimation of Retrofit Technology}

Staudt (2008) provided a means of estimating the capital costs for the energy efficiency measures using the following equation:

Capital Costs $(\$ 2008)=$ Scaleup factor $\times\left(\frac{\text { tons }}{\text { year }} \text { cement capacity }\right)^{m}$

where $m$ is the scale-up factor exponential.

Retrofits are carried out on a wet kiln and hence scale-up factors were extracted for wet kiln column from Staudt (2008). Meanwhile, scale-up factor using calculations from payback period was adopted. These costs however are subject to revalidation as this method only provides an estimation of equipment's capital cost only. The equation provided by Staudt (2008) is for 2008-dollar value. This value was normalized into present year using engineering economics techniques for finding a present worth of a future cost (past or later year).

For the purpose of this research, the equation above was used to model the case study plant. The case study cement plant is a wet process plant located in south western Nigeria. The plant runs a double firing system with natural gas and heavy oil as its sole kiln fuel. Carbon capture technology hasn't been discovered running on any cement plant everywhere throughout the world, the innovation is said to be in pilot stage at different research focuses yet notwithstanding, it has been exhibited in power plants and the prospects that it will work in a cement plant is high. Find below the details of the wet kiln used for this study (Table 1):

Table 1: Details of the wet kiln used for this study (Lafarge Nigeria, 2019)

\begin{tabular}{ccc}
\hline & Plant & Data \\
\hline Indicators & Unit & Accumulated Average \\
\hline Cement Output & Tonne/Year & 680,087 \\
Clinker Output & Tonne/Year & 568,470 \\
Cement-Clinker Ratio & Tonne/Tonne & 1.20 \\
Annual Cement Turnout & Tonne & 700,000 \\
\hline Type of Fuel & $\mathrm{N}$ & Natural Gas \\
Emission Tonne of Cement & Tonne/Tonne & 0.84 \\
Raw Material to Clinker Ratio & Tonne/Tonne & 1.54 \\
Total Emission & Tonne & 300,137 \\
$\mathrm{CO}_{2}$ to CaCO & & 0.44 \\
$\mathrm{CaCO}_{3}$ to Raw Material Ratio & Stoichiometric Ratio & 0.78 \\
Total Heat Consumed $_{\text {Heat Consumed }}$ & Tonne/Tonne & $3,420,105$ \\
\hline
\end{tabular}


Economic evaluation of hazard control technology in a wet process cement plant

Table 1: Continued...

\begin{tabular}{|c|c|c|}
\hline & Plant & Data \\
\hline Indicators & Unit & Accumulated Average \\
\hline Total Power Consumed & MWh & 82,530 \\
\hline Operating Cost & $\$$ & $27,835,961$ \\
\hline Total Heat Expenditure & $\$$ & $14,001,196$ \\
\hline Total Power Expenditure & $\$$ & $14,042,662$ \\
\hline Overall Operating Cost & $\$$ & $27,835,961$ \\
\hline Average Power Cost & $\$ / \mathrm{MWh}$ & 170.15 \\
\hline Power Cost in Cement & \$/Tonne & 19.89 \\
\hline Fuel Cost in Cement & \$/Tonne & 210.88 \\
\hline Energy Cost in Cement & $\$ / \$$ & 40.97 \\
\hline Expenditure up to Clinker & $\$$ & $48,060,980$ \\
\hline Production Cost up to Clinker & $\$ /$ Tonne & 84.55 \\
\hline Cement Cost in Bin & $\$ /$ Tonne & 91.45 \\
\hline Maintenance Cost & $\$$ & $6,377,919$ \\
\hline Raw Material Cost & \$/Tonne & 40.93 \\
\hline Overall Cost & $\$$ & $36,840,071$ \\
\hline
\end{tabular}

\section{Analysis of the Wet Process Plant}

As stated earlier; Adebiyi et al. (2015) has identified four technological approaches and eighteen combinations (for two production lines of wet kilns) of these technological approaches to reduce $\mathrm{CO}_{2}$ emissions at different reduction target (Table 2).

Table 2: Combinations (for two production lines of wet kilns) of technological approaches to reduce $\mathrm{CO}_{2}$ emissions at different reduction target (Adebiyi et al., 2015)

\begin{tabular}{cc}
\hline Reduction Target (\%) & Retrofit Technology \\
\hline 1.0 & $R_{12}, R_{13}$ \\
\hline 2.0 & $R_{12}, R_{13}$ \\
\hline 3.0 & $R_{12}, R_{13}, R_{23}$ \\
4.0 & $R_{12}, R_{22}$ \\
5.0 & $R_{12}, R_{22}$ \\
\hline 6.0 & $R_{12}, R_{22}, R_{23}$ \\
\hline 7.0 & $R_{12}, R_{14}, R_{22}$, \\
\hline 8.0 & $R_{12}, R_{22}, R_{24}$ \\
9.0 & $R_{12}, R_{14}, R_{22}, R_{24}$ \\
\hline 10.0 & $R_{12}, R_{14}, R_{22}, R_{24}$ \\
\hline 11.0 & $R_{12}, R_{13}, R_{14}, R_{22}, R_{23}, R_{24}$ \\
\hline 12.0 & $R_{11}, R_{12}, R_{14}, R_{22}, R_{24}$ \\
\hline 13.0 & $R_{11}, R_{12}, R_{14}, R_{22}, R_{24}$ \\
\hline 14.0 & $R_{11}, R_{12}, R_{14} R_{22}, R_{24}$ \\
\hline 15.0 & $R_{11}, R_{12}, R_{14} R_{21}, R_{22}, R_{24}$ \\
\hline 16.0 & $R_{11}, R_{12}, R_{22}, R_{14}, R_{21}, R_{22}, R_{23}, R_{24}$ \\
\hline 17.0 & $R_{11}, R_{12}, R_{22}, R_{14}, R_{21}, R_{22}, R_{23}, R_{24}$ \\
\hline 18.0 & $R_{11}, R_{12}, R_{22} R_{14}, R_{21}, R_{22} R_{23}, R_{24}$ \\
\hline
\end{tabular}

Where: $R_{11}$-Adjustable Speed Drive for Unit 1. $R_{12}$-Kiln Drive Efficiency Improvement for Unit 1. $R_{13}$-Recipricating Grate Coolers for Unit 1. R14-Process Control and Management System for Unit 1. R21-Adjustable Speed Drive for Unit 2. R22Kiln Drive Efficiency Improvement for Unit 2. R23-Recipricating Grate Coolers for Unit 2. R24-Process Control and Management System for Unit 2. $R_{11}$ to $R_{24}$ are binary variables i.e. variables takes values of 0 or 1 .

The wet kilns under consideration have output of 680,087 tons/year of cement for both units at 75\% utilization factor and can go well above this value if available resources are well utilized. From Equation 1; substitute for wet kilns output we have the expression for cost estimate of first cost of retrofit technology as follows: 


\section{Cost Saving Analysis of Retrofit Technology}

The cost saving at respective reduction target is expressed below as:

Cost saving on retrofit $(\%$ reduction target $)=$

[ annualized capital cost of retrofits + annualized $O \& M$ cost of retrofit]

- Associated cost saving on energy expenditure

The overall cost saving is given as:

Reductioninoverallcost (@\% \% reduction cost=

Total operating cost for the plant

+ Carbon tax on total emission (without retrofit)

-Cost saving on retrofit (@\% reductiontarget)

Carbontaxon total emission $($ without retrofit $)=$

Carbontax / ton $\times$ total emisson (ton)

\section{Analysis of First Cost and Energy Cost Saving of Retrofit Technology}

\section{Adjustable Speed Drive for Kiln 1 Fan}

From Equation 2 above,

Capital Costs $(\$ 2008)=$ Scale - up factor $\times(680,087)^{0.6}$

From Staudt (2008), the scale-up factor for adjustable speed drives is 158 . Hence,

Capital Costs $(\$ 2008)=158 \times(680,087)^{0.6}$

Capital Cost $(\$ 2008)=\$ 499,109$

Leveling the above dollar value to 2019 and assuming an interest rate of $10 \%$

Capital Cost $(\$ 2019)=499,109(F / P, 10 \%, 11)$

From interest table, $(F / P, 10 \%, 11)=2.853$

Capital Costs $(\$ 2019)=\$ 1,423,958$

Annualizing the above capital cost gives:

Annual capital cost $=$ Capital $\operatorname{Costs}(\$ 2019) \times(A / P, 10 \%, 10)$

Adjustable speed drives are classified to have a service life of $10 \mathrm{yrs}$ as obtained from the United States department of treasury, internal revenue service, 2010. 
Operating Cost of adjustable speed drives:

Power cost accounts for the chunk of the operating cost of speed drives, other costs however include maintenance cost and cost of rewinding.

Power cost estimation:

Parameters:

A $1000 \mathrm{HP}, 3000 \mathrm{rpm}$ variable speed drives under a $75 \%$ load and a 3 shift operation amounting to $8,000 \mathrm{hrs}$.

Power consumption is estimated as below:

$1 H P=0.746 \mathrm{KW}$

Therefore, $1000 \mathrm{HP}=746 \mathrm{KW}$

Total power consumed $=746 \times 75 \% \times 8000=4.48 \mathrm{MWH}$ per year

For industrial consumption, cost of electric power per kilowatt hour $=\$ 38.140 / \mathrm{KWh}$ at an exchange rate of $\$ 306$ to $\$ 1$ (average exchange rate for 2019),

Power $(\mathrm{KWh})=\$ 0.125$

Annual power cost $=\$ 558.39$

Annual maintenance cost is assumed to be $20 \%$ of capital cost, therefore, annualized total cost is:

Therefore, maintenance cost $=20 \% \times 1,423,958=\$ 284,792$

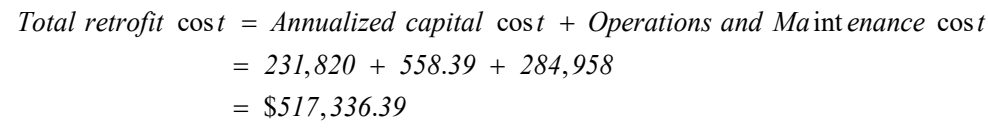

The United States Environmental Protection Agency (2008), provided a measure of efficiency associated with cement with cement plant retrofit and for adjustable speed drive for kiln fan, energy saving is stated as $5 \mathrm{KWh} /$ ton reduction in energy consumption.

Overall operating cost $=\$ 27,835,961$

Total power consumption: $\$ 14,042,662$

Cost saving from energy consumption reduction:

$1 \mathrm{MWH}=\$ 125$

Hence, $1 \mathrm{KWh}=\$ 0.125$

Cost saving $=5 \times 700,000 \times 0.125=\$ 437,500$

Cost saving on energy consumption represents $3.12 \%$ of total cost of power consumption and $1.57 \%$ of total operating cost.

\section{Kiln Drive Efficiency Improvement}

From Equation 2 above,

Capital costs $(\$ 2008)=$ scale - up factor $\times(680,087)^{0.6}$ 
Economic evaluation of hazard control technology in a wet process cement plant

From Staudt (2008), scale-up factor $=29$

Capital costs $(\$ 2008)=29 \times(680,087)^{0.6}=\$ 91,609$

Leveling the above dollar value to 2019 and assuming an interest rate of 10\%

Capital costs $(\$ 2019)=91,609(F / P, 10 \%, 11)$

From interest table, $(F / P, 10 \%, 11)=2.853$

Capital costs $(\$ 2019)=\$ 261,360$

Annualizing the above capital cost gives:

Annual capital cost $=$ capital cost $(\$ 2019) \times(A / P, 10 \%, 10)$

According to the United States Environmental Protection Agency (2008) Kiln drive efficiency improvement equipment is classified to have a service life of 10yrs.

Annualized capital cost $=261,360 \times 0.1628$

Annualized capital cost $=\$ 42,549$.

As assumed earlier, annual operating and maintenance cost is $20 \%$ of capital cost

Operating and Maintenance $=20 \% \times 261,369=\$ 52,272$

Total Retrofit Cost $=$ Annualized capital cost + operations and Maintenance cost

$=42,549+52,272$

$=\$ 94,821$

Efficiency improvement:

Efficiency was calculated from associated energy saving potential of retrofitted equipment. For kiln drive efficiency improvement, energy saving is stated as $0.5 \mathrm{KWh} /$ ton reduction in energy consumption (United States Environmental Protection Agency, 2008). Respective efficiency will be calculated for each unit of the plant based on its current electrical energy consumption.

Overall operating cost $=\$ 27,835,961$

Total power consumption: $\$ 14,042,662$

Cost saving from energy consumption reduction:

$1 \mathrm{MWH}=\$ 125$

Hence, $1 \mathrm{KWh}=0.125$

Cost saving $=0.5 \times 700,000 \times 0.125=\$ 43,750$

Cost saving on energy consumption represents $0.31 \%$ of total cost of power consumption and $0.16 \%$ of total operating cost.

\section{Reciprocating Grate Cooler}

From Equation 2 above,

Capital costs $(\$ 2008)=$ scale - up factor $\times(680087)^{0.6}$

From Staudt (2008), scale-up factor $=83$

Capital costs $(\$ 2008)=83 \times(680087)^{0.6}=\$ 262,190$

Leveling the above dollar value to 2019 and assuming an interest rate of 10\% 
Capital costs $(\$ 2019)=262,190(F / P, 10 \%, 11)$

From interest table,

$(F / P, 10 \%, 2)=2.853$

Capital Costs $(\$ 2019)=\$ 748,028$

Annualizing the above capital cost gives:

Annual capital cost $=$ capital costs $(\$ 2019) \times(A / P, 10 \%, 20)$

Cement manufacturing equipment such as coolers are classified to have a service life of 20yrs as obtained from the United States Environmental Protection Agency (2008).

Annualized capital cost $=748,028 \times 0.1175$

Annualized capital cost $=\$ 87,893$.

As assumed earlier, annual operating and maintenance cost is $20 \%$ of capital cost

Operating and Maintenance $=20 \% \times 748,028$

Operating and Maintenance $=\$ 149,606$

Total Retrofit Cost $=$ Annualized capital cost + operations and Maintenance cost

$=87,893+149,606$

$=\$ 237,499$

Efficiency improvement:

As obtained for adjustable speed drives, efficiency was calculated from associated energy (heat) saving potential of retrofitted equipment. For reciprocating grate coolers, energy saving is stated as $8 \%$ reduction per tonne in heat energy consumption (United States Environmental Protection Agency, 2008).

Present heat consumption: 976,310GJ

$8 \% \times 976,310=78,104.8 \mathrm{G} \mathrm{J}$

Average heat cost $=4.1 \$ / \mathrm{G}$

Total cost of heat consumption $=\$ 14,001,196$

Cost saving from heat energy consumption reduction:

$1 \mathrm{GJ}=\$ 4.1$

Hence, $78,104.8 \mathrm{GJ}=\$ 320,230$

Cost saving $=\$ 320,230$

Cost saving on heat energy consumption represents $2.29 \%$ of total cost of heat consumption and $1.15 \%$ of total operating cost.

\section{Process Control and Management Systems}

From Equation 2 above,

Capital costs $(\$ 2008)=$ scale - up factor $\times(680,087)^{0.6}$

From Staudt (2008), the scale-up factor for process control and management systems for kiln $=207$.

Hence, Capital costs $(\$ 2008)=207 \times(680,087)^{0.6}=\$ 653,897$

Leveling the above dollar value to 2019 and assuming an interest rate of $10 \%$ gives; 
Capital costs $(\$ 2019)=653,897(F / P, 10 \%, 11)$

From interest table,

$(F / P, 10 \%, 11)=2.853$

Capital Costs $(\$ 2019)=\$ 1,865,568$

Annualizing the above capital cost gives:

Annual capital cost $=$ capital costs $(\$ 2019) \times(A / P, 10 \%, 10)$

Process control and management systems are classified to have a service life of $10 y$ rs as obtained from the United States Environmental Protection Agency (2008).

Annualized capital cost $=\$ 1,865,568 \times 0.1628$

Annualized capital cost $=\$ 303,714$.

Annual operating and maintenance costs of process control and management system is assumed to be $20 \%$ of capital cost, hence $\mathrm{O} \& \mathrm{M}$ is given as

$O \& M=20 \% \times$ capital cost

$=20 \% \times 1,865,568=\$ 373,113$

Total Retrofit Cost $=$ Annualized capital cost + Annual Operations and Maintenance cost

$=\$ 303,714+373,113$

$=\$ 676,827$

Efficiency improvement:

The United States Environmental Protection Agency, (2008) provided a measure of efficiency associated with cement plant retrofit process control and management system is estimated to provide an energy reduction of $2.5-5 \%$ per $\mathrm{MJ} /$ ton of cement.

A 3.75\% per MJ/ton energy reduction representing the average of the value quoted by United States Environmental Protection Agency (2008), was selected.

Present heat consumption: 976,310GJ

$3.75 \% \times 976,310=36,612 \mathrm{GJ}$

Average heat cost $=4.1 \$ / G$ J

Total cost of heat consumption: $\$ 14,001,196$

Cost saving from heat energy consumption reduction:

$1 \mathrm{GJ}=\$ 4.1$

Hence, $36,612 \mathrm{GJ}=\$ 150,108$

Cost saving $=\$ 150,108$

Cost saving on heat energy consumption represents $1.07 \%$ of total cost of heat consumption and $0.54 \%$ of total operating cost.

\section{RESULTS}

This section presents the total cost of each retrofit technology (in terms of annualized capital cost and operating and maintenance cost) and its corresponding energy savings. Afterwards; the retrofit cost savings of combinations of retrofit technology as presented by Adebiyi et al., (2015) follow suit. The retrofit cost savings was evaluated in terms of total retrofit cost, energy savings of retrofit and cost of avoided emission (depending on the $\mathrm{CO}_{2}$ reduction target) for each combination of retrofit technology. 


\section{Costs of Retrofit Technology for Kiln 1 and Kiln 2}

Table 3 shows the cost of retrofit technology and energy savings for kiln 1 and kiln 2 . These costs were determined using the cost estimation methods and engineering economic techniques.

Table 3: Summary of Cost on for Retrofit Technology for Kiln 1 and Kiln 2

\begin{tabular}{ccccc}
\hline Retrofit Technology & $\begin{array}{c}\text { Annualized } \\
\text { Capital Cost (\$) }\end{array}$ & $\begin{array}{c}\text { Operating and } \\
\text { Maintenance Cost (\$) }\end{array}$ & $\begin{array}{c}\text { Total Retrofit } \\
\text { Cost (\$) }\end{array}$ & $\begin{array}{c}\text { Energy } \\
\text { Saving (\$) }\end{array}$ \\
\hline $\begin{array}{c}\text { Adjustable speed drive } \\
\mathrm{R}_{11} / \mathrm{R}_{21}\end{array}$ & 231,820 & 285,516 & 517,336 & 437,500 \\
\hline $\begin{array}{c}\text { Kiln drive efficiency } \\
\text { improvement } \mathrm{R}_{12} / \mathrm{R}_{22}\end{array}$ & 42,549 & 52,272 & 94,821 & 43,750 \\
\hline $\begin{array}{c}\text { Reciprocating grate } \\
\text { cooler } \mathrm{R}_{13} / \mathrm{R}_{23}\end{array}$ & 87,893 & 149,606 & 237,499 & 320,230 \\
\hline $\begin{array}{c}\text { Process control and } \\
\text { management system } \mathrm{R}_{14} / \\
\mathrm{R}_{24}\end{array}$ & 303,714 & 373,113 & 676,827 & 150,108 \\
\hline
\end{tabular}

Table 4 shows the direct annual gross carbon dioxide $\left(\mathrm{CO}_{2}\right)$ emission from cement production using the cement-based methodology tool developed by WRI and WBCSD, 2002. Using this tool, the annual $\mathrm{CO}_{2}$ emission was calculated from the plant data provided in Table 1 using the given annual cement production and other necessary factors required by the tool.

Table 4: Direct Annual Gross Carbon Dioxide Emissions from Cement Production

\begin{tabular}{|c|c|c|c|c|c|c|}
\hline A & B & C & D & $\mathbf{E}$ & $\mathbf{F}$ & G \\
\hline $\begin{array}{c}\text { Annual } \\
\text { Cement } \\
\text { Production } \\
\text { (tonnes/yr) }\end{array}$ & $\begin{array}{l}\text { Clinker to } \\
\text { Cement } \\
\text { Ratio (\%) }\end{array}$ & $\begin{array}{l}\text { Tonne of } \\
\text { Raw } \\
\text { Material } \\
\text { per Tonne } \\
\text { of Clinker }\end{array}$ & $\begin{array}{c}\mathrm{CaCO}_{3} \\
\text { Equivalent } \\
\text { Raw } \\
\text { Material } \\
\text { Ratio (\%) }\end{array}$ & $\begin{array}{c}\mathrm{CO}_{2} \text { to } \mathrm{CaCO}_{3} \\
\text { Stoichiometric } \\
\text { Ratio Constant }\end{array}$ & $\begin{array}{l}\text { Carbon Dioxide } \\
\text { Emissions } \\
\text { Factor (tonnes } \\
\mathrm{CO}_{2} / \text { tonnes } \\
\text { clinker } \\
\text { produced) B x C } \\
\text { X D x E }\end{array}$ & $\begin{array}{c}\text { Annual } \\
\text { Carbon } \\
\text { Dioxide } \\
\text { Emissions } \\
\text { (tonnes/yr) } \\
\text { A x F }\end{array}$ \\
\hline 680,087 & $84 \%$ & 1.54 & $78 \%$ & 0.44 & 0.44 & 300,137 \\
\hline
\end{tabular}

\section{Cost Savings on Retrofit/Economic analysis of CO2 reduction target}

Table 5 shows the reduction target of $\mathrm{CO}_{2}$ emission and the corresponding cost savings on retrofit. The retrofit cost saving is a function of total retrofit cost, energy saving of retrofit and cost of avoided emission for each combination of retrofit technology depending on the reduction target. For instance; consider cost saving on retrofit at $1 \%$, reduction, $R_{12}$ and $R_{13}$ were the retrofit technology chosen thereby reducing emission by 3,001 ton.

Where; $\mathrm{R}_{12}$ - Kiln Drive Efficiency Improvement for Kiln 1, $\mathrm{R}_{13}$ - Reciprocating Grate Coolers for Kiln 1

Cost of avoided emission $=\$ 30 \times 3,001.37=\$ 90,041.1$

Total retrofit cost (O\&M inclusive) for $R_{12} \& R_{13}=\$ 332,320$

Total Energy Cost Saving of Retrofit $=\$ 363,980$

Applying Equation 2, we have:

Cost saving $(1 \%$ reduction target $)=\$ 332320-\$ 363980-\$ 90041=-\$ 121701$

The negative sign is as a result of an accrued saving in term of cost reduction 
Table 5: Economic analysis of $\mathrm{CO}_{2}$ reduction target

\begin{tabular}{|c|c|c|c|c|c|c|}
\hline $\begin{array}{l}\text { Reduction } \\
\text { Target }\end{array}$ & $\begin{array}{c}\text { Retrofit } \\
\text { Technology }\end{array}$ & $\begin{array}{l}\text { Amount of } \\
\mathrm{CO}_{2} \text { emission } \\
\text { reduced } \\
\text { (Tons) }\end{array}$ & $\begin{array}{c}\text { Total } \\
\text { Retrofit } \\
\text { Cost (\$) A }\end{array}$ & $\begin{array}{c}\text { Total Energy } \\
\text { Cost Saving } \\
\text { of Retrofit B }\end{array}$ & $\begin{array}{l}\text { Cost of } \\
\text { avoided } \\
\text { emission } \\
\text { (\$) C }\end{array}$ & $\begin{array}{l}\text { Cost Saving on } \\
\text { Retrofit (@ \% } \\
\text { reduction } \\
\text { Target) A - } \\
\text { (B+C) }\end{array}$ \\
\hline $1 \%$ & $R_{12}, R_{13}$ & 3,001 & 332,320 & 363,980 & 90,041 & $-121,701$ \\
\hline $2 \%$ & $R_{12}, R_{13}$ & 6,003 & 332,320 & 363,980 & 180,082 & $-211,742$ \\
\hline $3 \%$ & $R_{12}, R_{13}, R_{23}$ & 9,004 & 569,819 & 684,210 & 270,123 & $-384,514$ \\
\hline $4 \%$ & $\mathrm{R}_{12}, \mathrm{R}_{22}$ & 12,005 & 189,642 & 87,500 & 360,164 & $-258,022$ \\
\hline $5 \%$ & $R_{12}, R_{22}$ & 15,007 & 189,642 & 87,500 & 450,206 & $-348,064$ \\
\hline $6 \%$ & $\mathrm{R}_{12}, \mathrm{R}_{22}, \mathrm{R}_{23}$ & 18,008 & 427,141 & 407,730 & 540,247 & $-520,836$ \\
\hline $7 \%$ & $\mathrm{R}_{12}, \mathrm{R}_{14}, \mathrm{R}_{22}$ & 21,010 & 866,469 & 237,608 & 630,288 & $-1,427$ \\
\hline $8 \%$ & $\mathrm{R}_{12}, \mathrm{R}_{22}, \mathrm{R}_{24}$ & 24,011 & 866,469 & 237,608 & 720,329 & $-91,468$ \\
\hline $9 \%$ & $\mathrm{R}_{12}, \mathrm{R}_{14}, \mathrm{R}_{22}, \mathrm{R}_{24}$ & 27,012 & $1,543,296$ & 387,716 & 810,370 & 345,210 \\
\hline $10 \%$ & $\mathrm{R}_{12,} \mathrm{R}_{14,} \mathrm{R}_{22}, \mathrm{R}$ & 30,014 & $1,543,296$ & 387,716 & 900,411 & 255,169 \\
\hline $11 \%$ & $\begin{array}{c}R_{12}, R_{13}, R_{14}, R \\
22, R_{23}, R_{24}\end{array}$ & 33,015 & $2,018,294$ & $1,028,176$ & 990,452 & -334 \\
\hline $12 \%$ & $\begin{array}{c}\mathrm{R}_{11}, \mathrm{R}_{12}, \mathrm{R}_{14}, \mathrm{R} \\
{ }_{22}, \mathrm{R}_{24}\end{array}$ & 36,016 & $2,060,632$ & 825,216 & $1,080,493$ & 154,923 \\
\hline $13 \%$ & $\begin{array}{c}\mathrm{R}_{11}, \mathrm{R}_{12}, \mathrm{R}_{14}, \mathrm{R} \\
{ }_{22}, \mathrm{R}_{24}\end{array}$ & 39,018 & $2,060,632$ & 825,216 & $1,170,534$ & 64,882 \\
\hline $14 \%$ & $\begin{array}{c}R_{11}, R_{12}, R_{14} R \\
22, R_{24}\end{array}$ & 42,019 & $2,060,632$ & 825,216 & $1,260,575$ & $-25,159$ \\
\hline $15 \%$ & $\begin{array}{c}R_{11}, R_{12}, R_{14} R \\
21, R_{22}, R_{24}\end{array}$ & 45,021 & $2,577,968$ & $1,262,716$ & $1,350,617$ & $-35,365$ \\
\hline $16 \%$ & $\begin{array}{c}\mathrm{R}_{11}, \mathrm{R}_{12}, \mathrm{R}_{22}, \mathrm{R} \\
{ }_{14}, \mathrm{R}_{21}, \mathrm{R}_{22}, \mathrm{R}_{23}, \\
\mathrm{R}_{24}\end{array}$ & 48,022 & $2,910,288$ & $1,626,696$ & $1,440,658$ & $-157,066$ \\
\hline $17 \%$ & $\begin{array}{c}R_{11}, R_{12}, R_{22}, R \\
14, R_{21}, R_{22}, R_{23} \\
R_{24}\end{array}$ & 51,023 & $2,910,288$ & $1,626,696$ & $1,530,699$ & $-247,107$ \\
\hline $18 \%$ & $\begin{array}{c}R_{11}, R_{12}, R_{22} R \\
{ }_{14} R_{21}, R_{22} R_{23} \\
R_{24} \\
\end{array}$ & 54,025 & $2,910,288$ & $1,626,696$ & $1,620,740$ & $-337,148$ \\
\hline
\end{tabular}

Table 6 shows the total cost on retrofit at various reduction targets by evaluating the overall operating and maintenance cost without retrofit with $\mathrm{CO}_{2}$ tax and cost savings on each retrofit to determine the percentage reduction in cost for each percentage reduction target. The carbon tax on total emission (without retrofit) was calculated using Equation 6 while the total cost in a carbon era was calculated using Equation 7 as stated below:

Carbon tax on total emission (without retrofit) $=$ Carbon tax/ton $\times$ total emission (ton) 6

Carbon tax on total emission (without retrofit) $=\$ 30 /$ ton $\times 300,137=\$ 9,004,110$

Total cost with retrofit in a carbon tax era $=$

Total operating cost for the plant

+ Carbon tax on total emission (without retrofit)

-Cost saving on retrofit(@\%reductiontarget) 
Note that the total operating cost (without retrofit) is $\$ 27,835,961$.

Therefore at reduction target of $1 \%$, the total cost on retrofit is calculated thus:

Total cost of the cement plant on Retrofit $=$

$\$ 27,835,961+\$ 9004110-\$ 121701=\$ 36,718,370$

Table 6: Total Cost Spent on Retrofit Technology and Percentage Reduction in overall Operating Cost

\begin{tabular}{|c|c|c|c|c|c|}
\hline $\begin{array}{l}\text { Reduction } \\
\text { Target (\%) }\end{array}$ & $\begin{array}{c}\text { Total O\&M (No } \\
\text { Retrofit) (\$) A }\end{array}$ & $\mathrm{CO}_{2} \operatorname{Tax}(\$) \mathrm{B}$ & $\begin{array}{c}\text { Cost Saving on } \\
\text { Retrofit (@\% } \\
\text { reduction Target) } \\
\text { C }\end{array}$ & $\begin{array}{l}\text { Total Cost } \\
\text { with Retrofit } \\
\text { (\$) } A+B+C\end{array}$ & $\begin{array}{l}\text { Reduction in Cost } \\
(\%)\end{array}$ \\
\hline 1 & $27,835,961$ & $9,004,110$ & $-121,701$ & $36,718,370$ & 0.33 \\
\hline 2 & $27,835,961$ & $9,004,110$ & $-211,742$ & $36,628,329$ & 0.57 \\
\hline 3 & $27,835,961$ & $9,004,110$ & $-384,514$ & $36,455,557$ & 1.04 \\
\hline 4 & $27,835,961$ & $9,004,110$ & $-258,022$ & $36,582,049$ & 0.70 \\
\hline 5 & $27,835,961$ & $9,004,110$ & $-348,064$ & $36,492,007$ & 0.94 \\
\hline 6 & $27,835,961$ & $9,004,110$ & $-520,836$ & $36,319,235$ & 1.41 \\
\hline 7 & $27,835,961$ & $9,004,110$ & $-1,427$ & $36,838,644$ & 0.004 \\
\hline 8 & $27,835,961$ & $9,004,110$ & $-91,468$ & $36,748,603$ & 0.25 \\
\hline 9 & $27,835,961$ & $9,004,110$ & 345,210 & $37,185,281$ & -0.94 \\
\hline 10 & $27,835,961$ & $9,004,110$ & 255,169 & $37,095,240$ & -0.69 \\
\hline 11 & $27,835,961$ & $9,004,110$ & -334 & $36,839,737$ & 0.0009 \\
\hline 12 & $27,835,961$ & $9,004,110$ & 154,923 & $36,994,994$ & -0.42 \\
\hline 13 & $27,835,961$ & $9,004,110$ & 64,882 & $36,904,953$ & -0.18 \\
\hline 14 & $27,835,961$ & $9,004,110$ & $-25,159$ & $36,814,912$ & 0.07 \\
\hline 15 & $27,835,961$ & $9,004,110$ & $-35,365$ & $36,804,706$ & 0.10 \\
\hline 16 & $27,835,961$ & $9,004,110$ & $-157,066$ & $36,683,005$ & 0.43 \\
\hline 17 & $27,835,961$ & $9,004,110$ & $-247,107$ & $36,592,964$ & 0.67 \\
\hline 18 & $27,835,961$ & $9,004,110$ & $-337,148$ & $36,502,923$ & 0.92 \\
\hline
\end{tabular}

\section{DISCUSSION}

The plant under consideration has an annual carbon dioxide emission of 300,137 tonnes and overall plant operating cost is $\$ 27,835,961$. Also, the plant uses two Kilns for its clinker production. Emission cost is benchmarked at $\$ 30 /$ ton of emission. This is based on the average dollar value as proposed by most countries. Meaning, in a regime of carbon tax, an astounding sum of $\$ 9,004,110$ would be paid on total emission bringing overall operating cost to $(\$ 27,835,961+\$ 9,004,110)$. An optimization model whose objective was to identify the best retrofit technology strategy to reduce $\mathrm{CO}_{2}$ emanations with the least cost has been developed by Adebiyi et al. (2015) using the industry data. This research therefore evaluated the economic worthwhile of retrofit technology strategy selected for $\mathrm{CO}_{2}$ reduction by Adebiyi et al. (2015).

At a reduction target of $1 \%$ to $2 \% ; 3,001$ to 6,003 tonnes of carbon dioxide were reduced. Tables 5 and 6 shows the retrofit technology selected namely; kiln drive efficiency improvement for kiln 1 and reciprocating grate coolers for kiln 1 . The result shows a $\$ 121,701$ in cost savings on retrofit and a $0.57 \%$ reduction in total cost on retrofit. It was observed that at reduction target of $9 \%, 10 \%, 12 \%$ and $13 \%$, the cost saving on retrofit was not economically 
worthwhile selected for the combination of retrofit technology strategy at each reduction target respectively. Instead of reduction in cost with the strategies, there was increase in cost making such combination of technology not economically worthwhile at those reduction target listed in Table 6. The negative sign in the percentage reduction in cost in Table 6 shows an increase in total cost on retrofit. Although at reduction targets of $9 \%, 10 \%, 12 \%$ and $13 \%$, Table 5 shows there is reduction in $\mathrm{CO}_{2}$ emission making the retrofit technology efficient in reducing carbon dioxide emission but not economical in terms of cost reduction.

Further economic analysis at other reduction targets shows the cost savings and percentage reduction in total cost on retrofit. At reduction targets of $2 \%, 4 \%, 5 \%, 6 \%, 17 \%$ and $18 \%$; there is economic worthwhile of these retrofit technologies in terms cost savings and percentage reduction in total cost on retrofit with reduction target of $6 \%$ giving the best economic viability amongst the aforesaid.

Carbon Emissions Trading on the Floor of the Exchange is policy under consideration by the Federal Government of Nigeria. This carbon trading is fashioned after the Emission Trading Scheme (ETS) that is fully underway in Europe as a method of fighting emissions with the aid of established emission standards or caps, which restrict how much an entity/organization/country is permitted to emit, and to buy/promote the excess/savings. As a machine of governance through markets, carbon trading relies on the allocated performance of marketplace agents to provide the proper indicators for innovative and effective ways of pursuing economic activities, more so for ensuring socioeconomic optimality within the use of public goods, the climate being a regular example. The availability of two external agents, a regulator (government organisation) and a broking firm (trading platform) represent the vital and sufficient circumstances for the workability of carbon buying and selling. These vital and sufficient circumstances are fulfilled in Nigeria through the Ministry of Environment acting as the regulator whiles the Nigerian Stock Exchange acting as the broking firm (Onyeka, 2020). With this in the pipeline, it is evident that the Nigeria government is fully committed to the reducing $\mathrm{CO}_{2}$ emanations in all sectors of Nigeria economy and that all sectors of the economy should brace up for carbon tax regime which is imminent.

In this research, the economic viability of combination of four retrofit technologies to reduce $\mathrm{CO}_{2}$ emanation and minimize operating cost were considered which revealed reduction targets in terms of cost savings and percentage reduction in total cost on retrofit. The research also showed some cases where the combinations of this technology were not economical in term of cost savings and percentage reduction in total cost on retrofit.

\section{CONCLUSION}

The cement industry is responsible for the contribution of global carbon dioxide emanation emitted from the calcination process of limestone. $\mathrm{CO}_{2}$ emanations have contributed to a large scale climate change which has global repercussions. There are technologies that mitigate the release or capture $\mathrm{CO}_{2}$ emanation. The combinations of these retrofit technologies are quoted to reduce emission, reduce heat and electrical energy consumption and by extension reduce the operating and maintenance cost as well as increase in productivity of the production line. So, it is the main goal of this research to evaluate the economic viability of implementing these retrofit technologies.

Engineering economics and cost estimation techniques were used to evaluate the economic viability of implementing these retrofit technologies in terms of cost savings on retrofit and percentage reduction in total cost on retrofit. The best strategy to reduce $\mathrm{CO}_{2}$ emanation economically is the combination of $R_{12}, R_{22}$ and $R_{23}$ retrofit technologies at $6 \%$ reduction target, giving a cost saving of $\$ 520,836$ on retrofit and $1.41 \%$ reduction in total cost.

It should be noted that this research only implemented the use of technology as a way of reducing $\mathrm{CO}_{2}$ emanations in the cement industry. Due to the rate at which carbon dioxide is been emitted in the cement industry, the government should implement carbon tax on the cement industry so as to hold the cement companies responsible for the $\mathrm{CO}_{2}$ emanations. If set high enough, it turns into a powerful financial motivator that motivates changes to clean 
energy across the economy, essentially by making it more economically rewarding to move to less carbon concentrated manufacturing techniques. Cement plant operators should be compelled to adhere to strict environmental, safety regulations, litigations and sanctions can be employed to implements this regulation.

\section{REFERENCES}

Adebiyi, K.A., Akinyemi, O.O., Akintan, A.L. et al. (2015), "Modelling the hazard control in a wet process plant- a case of cement plant", Brazilian Journal of Operations \& Production Management, Vol. 12, pp. 338-48.

Cervigni, R. and John Rogers, J.A. and Dvorak, I. (2013). Assessing low-carbon development in Nigeria: an analysis of four sectors: a World Bank study. The World Bank, Washington D.C., USA.

Ezema, I.C., Opoko, A.P. and Oluwatayo, A.A. (2016), "De-carbonizing the Nigerian housing sector: the role of life cycle $\mathrm{CO}_{2}$ assessment", International Journal of Applied Environmental Sciences., Vol. 11, No. 1, pp. 325-49.

Farfan, J., Fasihi, M. and Breyer, C. (2019), "Trends in the global cement industry and opportunities for long-term sustainable CCU potential for Power-to-X", Journal of Cleaner Production, Vol. 217, pp. 821 35. http://dx.doi.org/10.1016/j.jclepro.2019.01.226.

Gardarsdottir, S.O., Lena, E.D., Romano, M. et al. (2019), "Comparison of technologies for $\mathrm{CO}_{2}$ capture from cement production - part2: cost analysis", Energies, Vol. 2019, No. 12, pp. 542.

Global Cement (2011), "An introduction to the World's most important building material", available at: https://www.globalcement.com/magazine/articles/490-cement-101-an-introduction-to-the-worldsmost-important-building-material (accessed 4 April 2019).

International Energy Agency (2010), “Cement production: IEA ETSAP - Technology Brief I03”, available at: https://iea-etsap.org/E-TechDS/PDF/I03_cement_June_2010_GS-gct.pdf (accessed 4 April 2019).

International Energy Agency, Cement Sustainability Initiative (2018), "Technology roadmap-lowcarbon transition in the cement industry", available at: https://www.iea.org/publications/freepublications/publication/TechnologyRoadmapLowCarb onTransitionintheCementIndustry.pdf (accessed 4 April 2019).

Jessica, N.F. (2018), "The role of industrial carbon capture and storage in emissions mitigation", available at: https://globalchange.mit.edu/sites/default/files/Farrell_MS_2018.pdf (accessed 7 April 2019).

Leeson, D., Mac Dowell, N., Shah, N. et al. (2017), "A Techno-economic analysis and systematic review of carbon capture and storage (CCS) applied to the iron and steel, cement, oil refining and pulp and paper industries, as well as other high purity sources", International Journal of Greenhouse Control., Vol. 61, pp. 71-84.

Maddalena, R., Roberts, J.J. and Hamilton, A. (2018), "Can Portland cement be replaced by low carbon alternative materials? A study on the thermal properties and carbon emissions of innovative cements", Journal of Cleaner Production, Vol. 186, pp. 933-42.

Naqi, A. and Jang, J.G. (2019), "Recent progress in green cement technology utilizing low carbon emission fuels and raw materials: a review", Sustainability, Vol. 2019, No. 11, pp. 537.

Nigeria, L. (2019), Details of the Cement Plant. Sagamu, Ogun State.

Onyeka, K. (2020), "Carbon trading as an option for Greening Nigeria's economy", available at: http://cpparesearch.org/nu-en-pl/carbon-trading-option-greening-nigerias-economy/ (accessed 16 July 2020).

Sidhi, M.P., Anoop, S.G., Naveen, G. et al. (2016), "A review article on manufacturing process of cement, environmental attributes, topography and climatological data station: IMD", Journal of Medicinal Plants Studies, Vol. 4, No. 4, pp. 47-53.

Staudt, J. (2008), Memorandum to Ravi Srivastava, Samudra Vijay, and Elineth Torres. Costs and Performance of Controls. Andover Technology Partners.

Sulaiman, C. and Abdul-Rahim, A.S. (2018), "Population growth and CO2 emission in Nigeria: a recursive ARDL approach", SAGE Open, 1-14.

Summerbell, D.L., Barlow, C.Y. and Cullen, M.J. (2016), "Potential reduction of carbon emissions by performance improvement: a cement industry case study", Journal of Cleaner Production, Vol. 135, pp. 1327-1339. 
United Stated Department of Treasury, Internal revenue Service 2010" have been removed from the text and replaced with United State Environmental Protection Agency, (2008)

United States Environmental Protection Agency (2008), Available and Emerging Technologies for Reducing Greenhouse Gas Emissions from The Portland Cement Industry. North Carolina, United States.

Author contributions: Olasunkanmi Oriola Akinyemi (Introduction, methodology and results/discussion). Hezekiah Oluwole Adeyemi: (Literature review and revisions). Adeshinaayomi Lawal Akintan: (Methodology and Results). Musediq Adedoyin Sulaiman: (Revisions). Ademola Oluwafemi Sadiq: (Data Collection). Olaolu Folorunsho: (Revisions). 